\title{
Presence of a Sexual Population of Puccinia graminis f. sp. tritici in Georgia Provides a Hotspot for Genotypic and Phenotypic Diversity
}

\author{
Pablo D. Olivera, ${ }^{1}$ Zoya Sikharulidze, ${ }^{2}$ Rusudan Dumbadze, ${ }^{2}$ Les J. Szabo, ${ }^{3}$ Maria Newcomb, ${ }^{1}$ Ketino Natsarishvili, ${ }^{2}$ \\ Matthew N. Rouse, ${ }^{3}$ Douglas G. Luster, ${ }^{4}$ and Yue Jin ${ }^{3, \dagger}$ \\ ${ }^{1}$ Department of Plant Pathology, University of Minnesota, St. Paul, MN 55108, U.S.A. \\ ${ }^{2}$ Batumi Shota Rustaveli State University, Institute of Phytopathology and Biodiversity, Kobuleti, Adjara, Georgia, U.S.A. \\ ${ }^{3}$ U.S. Department of Agriculture-Agricultural Research Service, Cereal Disease Laboratory, University of Minnesota, St. Paul, MN \\ 55108, U.S.A. \\ ${ }^{4}$ U.S. Department of Agriculture- Agricultural Research Service, Foreign Disease-Weed Science Research Unit, Ft. Detrick, MD 21702, U.S.A. \\ Accepted for publication 22 July 2019.
}

\begin{abstract}
Wheat stem rust, caused by Puccinia graminis f. sp. tritici, is a reemerging disease exemplified by recent epidemics caused by new virulent races. Understanding the sources and origins of genetic variations in the pathogen populations globally can facilitate the development of better strategies in disease management. We analyzed 68 wheat stem rust samples collected between 2013 and 2015 from Georgia where stem rust incidences are frequent and the alternate host, common barberry, is present. A total of 116 single-pustule isolates were derived and evaluated on stem rust differential lines to determine the virulence phenotypes and 23 races

programs because many of these genes are used in breeding for resistance to the $\mathrm{Ug} 99$ race group. Sixty-one isolates were genotyped using a custom single-nucleotide polymorphism chip and 17 genotypes were identified. The 2013 isolates contained 11 multilocus genotypes compared with isolates of 2014 and 2015, with five and three genotypes, respectively. The higher levels of virulence and genotypic diversity observed in the 2013 samples strongly indicated that sexual recombination occurs in the Georgian P. graminis f. sp. tritici population, and that the Caucasus region of Eurasia may be an important source of new races.
\end{abstract} were identified, many of which were detected for the first time. Unique virulence combinations including, $\operatorname{Sr} 22+\operatorname{Sr} 24$ and $\operatorname{Sr} 13 b+\operatorname{Sr} 35+\operatorname{Sr} 37$ were detected. These virulence combinations pose new challenges to breeding
Keywords: ecology and epidemiology, genetics and resistance, genotyping, population biology, race typing, surveillance, wheat stem rust
Wheat stem rust, caused by Puccinia graminis f. sp. tritici, is a reemerging disease that poses a significant threat to wheat production worldwide (Singh et al. 2015). The occurrence and spread of Sr31virulent races in the Ug99 race group in East Africa (Newcomb et al. 2016; Pretorius et al. 2000; Singh et al. 2015) and other races cause severe epidemics and localized outbreaks in Ethiopia (Olivera et al. 2015), Europe (Bhattacharya 2017; Olivera Firpo et al. 2017; A. Berlin, personal communication) and Central Asia (Shamanin et al. 2018), which is indicative of a strong comeback of this devastating disease. Race TKTTF, first reported in Turkey (Mert et al. 2012), has been detected across the Middle East (Singh et al. 2015), eastern Africa (Olivera et al. 2015), Germany (Olivera Firpo et al. 2017),

${ }^{\dagger}$ Corresponding author: Y. Jin; Yue.Jin@ars.usda.gov

Current address of M. Newcomb: University of Arizona, School of Plant Sciences, Maricopa, AZ 85138.

Funding: This research was funded by United States Department of AgricultureAgricultural Research Service and the Durable Rust Resistance in Wheat and Delivering Genetic Gain in Wheat projects administrated by Cornell University (grants DRRW-OPPGD1389 and DGGW-OPP1133199 were funded by the Bill and Melinda Gates Foundation and the United Kingdom Department for International Development). Mention of trade names or commercial products in this publication is solely for the purpose of providing specific information and does not imply recommendation or endorsement by the U.S. Department of Agriculture. The USDA is an equal opportunity provider and employer.

*The $\boldsymbol{e}$-Xtra logo stands for "electronic extra" and indicates that three supplementary tables are published online.

The author(s) declare no conflict of interest.

Copyright (c) 2019 The Author(s). This is an open access article distributed under the CC BY 4.0 International license. and England (Lewis et al. 2018). Since 1999, when first reported in Uganda (Pretorius et al. 2000), the TTKSK (or Ug99) race group has been rapidly evolving and expanding its geographical range. To date, 11 races of the $\mathrm{Ug} 99$ race group have been identified in eastern Africa and the Middle East (Newcomb et al. 2016; Singh et al. 2015), and it is projected to spread further, threatening critical wheat-growing regions in the world (Park et al. 2011).

Wheat stem rust is a windborne disease, and uredinospores can be disseminated over long distances following the prevailing winds affecting wheat crops across regions and continents. Understanding the sources and origins of genetic variation in the pathogen populations globally can facilitate the development of better strategies in disease management. Wheat stem rust is a common disease in Georgia, and its incidence and severity vary between years, locations, and cultivars. Because fungicide application is not commonly practiced by Georgian farmers (Sikharulidze et al. 2009), stem rust infections may be observed frequently in wheat fields. Sikharulidze et al. (2015) reported mean stem rust incidence and severity of 8 and $11 \%$, respectively, in the national rust surveys from 2009 until 2013, and the main wheat cultivars grown in the country (Bezostaya 1 and other Russian varieties) were moderately susceptible. In 2014 and 2015, higher stem rust infection rates were observed in the country. In 2014, disease severity and incidence in the main wheat-growing regions were up to 80 and $50 \%$, respectively; however, in 2015, disease severity and incidence were 50 and $30 \%$, respectively (Z. Sikharulidze, unpublished data). In addition, common barberry (Berberis vulgaris L.), the alternate host of $P$. graminis, is widely distributed in the main wheat-growing regions of Georgia (Ketskhoveli and Gagnidze 2007). There is limited information about the stem rust population in Georgia and the potential roles that the alternate host may play in pathogen variation and disease epidemiology. Since the occurrence and 
spread of races in the $\mathrm{Ug} 99$ group in East Africa and Middle East, efforts have been made regarding surveillance and pathogen monitoring in the main wheat-growing regions in the country. The objective of this study was to investigate virulence and genotypic diversity of the contemporary $P$. graminis population.

\section{MATERIALS AND METHODS}

Stem rust sample collection. A total of 90 samples of P. graminis f. sp. tritici-infected wheat tissues were collected during the crop seasons in 2013 (40), 2014 (15), and 2015 (35). Passport data of the samples (locations and cultivars) are provided in Supplementary Table S1. Urediniospore cultures were produced and stored in glass tubes after desiccation. Dried spores of each sample were mailed to the USDA-ARS Cereal Disease Laboratory (CDL) in St. Paul, MN, or the Foreign Disease-Weed Science Research Unit (FDWSRU) in Ft. Detrick, MD. Shipping and receiving protocols were followed according to the USDA APHIS PPQ permit conditions for handling international cultures of $P$. graminis $\mathrm{f}$. sp. tritici. Cultures received at FDWSRU were increased on the susceptible wheat McNair 701 (CItr 15288) and collected in gelatin capsules (size 00). After being increased, cultures were stored in a $-80^{\circ} \mathrm{C}$ freezer and shipped to CDL after December 1. Cultures received at the CDL were stored in $\mathrm{a}-80^{\circ} \mathrm{C}$ freezer until processing.

Race identification and characterization. The North American stem rust differential set (Roelfs et al. 1992; Roelfs and Martens 1988) that was modified to further delineate $P$. graminis $\mathrm{f}$. sp. tritici races in the TTKS race group (Jin et al. 2008) was used for race identification. All samples and isolates were further characterized on additional monogenic lines carrying the following resistance genes: $\mathrm{Sr} 13 a, \mathrm{Sr} 22$, Sr25, Sr26, Sr27, Sr28, Sr32, Sr35, Sr37, Sr39, Sr40, Sr44, Sr45, Sr47, Sr50, SrSatu, and the 1AL.1RS translocation in winter wheat (Sr1RSAmigo) (Olivera Firpo et al. 2017). Durum cultivars Iumillo $(\operatorname{Sr} 9 g, 12,+)$ and Leeds $(\operatorname{Sr} 9 e, 13 b,+)$ were also included in the evaluation. Each sample was first inoculated onto the differential and additional monogenic lines set. One to eight single-pustule isolates were derived from each original sample, primarily from differential lines, but also from the additional resistant lines when high-infection pustules were observed. Experimental procedures for inoculation, incubation, and disease assessment were performed as described by Jin et al. (2007) and Olivera et al. (2015). Single-pustule-derived cultures (pure cultures) were evaluated on differential lines and the set of additional resistance lines. Evaluations of the differential set were repeated two to five times before a race phenotype was designated. Race designation was based on the letter code proposed by Roelfs and Martens (1988). Urediniospores from all pure cultures were increased in isolation on the susceptible wheat McNair 701 and Line $\mathrm{E}$ and stored at $-80^{\circ} \mathrm{C}$.

Genotyping. DNA was extracted from either purified urediniospores or $P$. graminis f. sp. tritici-infected wheat leaf tissue (Olivera et al. 2015). Genotyping was performed using a custom Illumina Infinium single-nucleotide polymorphism (SNP) array (PgtSNP 3.0k chip) as described by Newcomb et al. (2016). From the initial set of 2718 markers, a total of 2305 were used based on the following criteria: GenTran score $>0.6$ and $\geq 90 \%$ call rate. GenTran scores and call rates are standard quality-control measures in GenomeStudio for SNP calling (Zhao et al. 2018). The dataset was further refined to 1999 SNP loci by removing markers where $>2 \%$ of the samples had missing calls. Duplicates of all DNA samples were included, and inconsistency between replicates was scored as missing data. An analysis of the final dataset containing 1999 SNP loci was performed using R (version 3.4.3; R Core Team, Vienna, Austria) with the package Poppr version 2.6.1 (Kamvar et al. 2015). For the phylogenetic analysis, a distance matrix was calculated using Nei's distance (Nei 1972, 1978). A neighbor-joining (Saitou and Nei 1987) tree was constructed using this distance matrix, and bootstrap values were calculated using 5000 sample replicates and a
$75 \%$ cutoff using the aboot function. Twenty-six reference isolates representing clades $\mathrm{I}-\mathrm{V}$ and a set of six U.S. isolates were also included in this analysis (Supplementary Table S2). To determine if SNP loci were in linkage disequilibrium, the standardized index of association rbar $_{\mathrm{d}}$ (Agapow and Burt 2001) was calculated with 999 permutations.

Phenotypic and genotypic diversity. Diversity for virulence phenotypes was estimated using Shannon's diversity index $(H)$, where $H=-\sum p i \ln (p i)$ in $p i$ is the frequency of the $i$ th phenotype (Groth and Roelfs 1987). Shannon's diversity index was calculated for each of the sampling seasons. Genotypic diversity was measured using Stoddart and Taylor's Index of multilocus genotype (MLG) diversity (Stoddart and Taylor 1988), with the SNP dataset with all missing data removed.

\section{RESULTS}

From the 90 P. graminis f. sp. tritici samples shipped to the U.S. laboratories, 68 remained viable after transit from Georgia: 24/40 in $2013,15 / 15$ in 2015 , and $29 / 35$ in 2015. From these 68 viable samples, 116 single-pustule isolates were derived and $23 P$. graminis f. sp. tritici races were identified. Races identified from the sampled regions are provided in Figure 1. Sixteen races were identified from 24 samples collected in 2013 (Table 1). The most predominant race was PRCQP (seven samples), followed by PTCTF, PRCQC, and PRCTF (five samples each) (Table 2). The remaining 12 races were each obtained from fewer than three samples. Most of the races identified in 2013 have a low-virulence spectrum, being avirulent especially to resistance genes $\mathrm{Sr} 8 \mathrm{a}, \mathrm{Sr} 10, \mathrm{Sr} 21, \mathrm{Sr} 30$, and $\mathrm{Sr} 36$ from the differential set. Only one (PRPTF) of the 16 races exhibited a high infection type (IT) on Sr36. Four races with virulence to resistance gene $\mathrm{Sr} 24$ were identified. All isolates were avirulent to $\mathrm{Sr} 31$. Tests of additional stem rust resistance genes conducted on the 2013-derived isolates detected virulence on $\operatorname{Sr} 22, \operatorname{Sr} 28, \operatorname{Sr} 35$, and Sr44 (Table 2). Virulence on $\mathrm{Sr} 22$ was present in two races (PRCTF and PRCTM). Of note, race PRCTM has combined virulence to resistance genes $\mathrm{Sr} 22$ and $\mathrm{Sr} 24$. Not all the isolates typed as race PRCTF exhibited high IT on $\mathrm{Sr} 22$. Isolate 13GEO08-1 was avirulent on $\mathrm{Sr} 22$ (IT =2-), whereas isolate 13GEO35-4 was virulent to this gene (IT =3) (Table 2). These isolates are considered different physiologic races even though their five-letter codes were unable to delineate the differences on virulence profiles. Two and four races were virulent on $\mathrm{Sr} 28$ and $\mathrm{Sr} 44$, respectively. Virulence to resistance gene $\operatorname{Sr} 35$ was observed in only one race (PRPTF).

Six and five $P$. graminis f. sp. tritici races were identified from 15 and 29 samples collected in 2014 and 2015, respectively (Table 3). Two races obtained in 2014 (PKPTF and TTRTF) were also observed in the 2015 samples. Races TKFTF and TKPTF were also observed in both 2014 and 2015, but the isolates collected across years are not considered the same races because they differ in the virulence on genes $S r 35$ and $S r 45$. Isolates typed as races TKFTF and TKPTF from 2014 exhibited low virulence on Sr35 and Sr45, whereas 2015 isolates of both races were virulent to both resistance genes (Tables 4; Supplementary Table S3). In 2014, race PKPTF was typed from $67 \%$ of the processed samples, and the remaining five races were observed in only 20 (PKPTC and TKPTF) and 7\% (PRDSC, TKFTF, and TTRTF) of the 15 samples (Table 4). In 2015, TTRTF (39\%) and TKFTF (35\%) were the predominant races obtained from the 29 samples evaluated. Most of the races obtained in 2014 and 2015 were virulent on $S r 8 a, S r 10, S r 21$, and $S r 36$ from the differential set (Table 3). Virulence on $\mathrm{Sr} 24$ and $\mathrm{Sr} 31$ was not detected in the races identified from the 2014 and 2015 collections. Tests of additional stem rust resistance genes detected virulence on $\mathrm{Sr} 13 b, \mathrm{Sr} 28, \mathrm{Sr} 35, \mathrm{Sr} 37, \mathrm{Sr} 44$, and $\mathrm{Sr} 45$ (Table 4). All the races obtained in 2014 and 2015 were virulent on Sr28. Virulence on $\mathrm{Sr} 44$ was also detected in most of the races. Virulence on Sr35 was detected in one race from 2014 and in four races from 2015.

Race TTRTF has the widest virulence spectrum of all races identified in Georgia during 2013 to 2015; it has virulence to a 
number of important resistance genes including $\operatorname{Sr} 36, \mathrm{Sr} 38$, and SrTmp from the differential set and Sr13b, Sr35, Sr37, and Sr45 (Fig. 2; Tables 3 and 4). Although race TTRTF was virulent on durum cultivar Leeds ( $\mathrm{Sr} 9 e$ and $\mathrm{Sr} 13 b$ ), it was avirulent on $\mathrm{Sr} 13 a$ (Fig. 2). Race TTRTF produced moderately high IT $(2+$ or $2+3)$ on $\mathrm{Sr} 50$ (Table 4). All other isolates described in this study displayed much lower ITs (2- or lower) on Sr50.

Several races identified in this study exhibited an IT on differential line VPM1 that ranged from 2- to $32+$ (Tables 2 and 4 ), which does not correspond to the expected low ITs that are characteristic of $S r 38$ (IT = ; to 31;). To confirm if these unusual low ITs were caused by $\operatorname{Sr} 38$, we evaluated $124 \mathrm{~F}_{2: 3}$ families from a cross between LMPG-6 $\times$ VPM1 against $P$. graminis $\mathrm{f}$. sp. tritici races QFCSC (isolate 06ND76C; IT = ; on VPM1) and PRCTF (isolate 13GEO35-4; IT = 2 on VPM1). Of the 124 LMPG-6/VPM-1 $\mathrm{F}_{2: 3}$ families assessed with race PRCTF, 107 families possessed at least 14 seedlings from a total of 24 seeds planted per family. Plants varied in response to race PRCTF from IT 2- to 3+, but ITs that are characteristic for $\mathrm{Sr} 38$ were not observed. Of these families, 24 possessed resistant plants, 31 possessed susceptible plants, and 52 were heterogeneous for resistant and susceptible plants. The ratio of resistant:heterogeneous:susceptible families was $1: 2: 1$, indicative of a single gene conferring resistance to race $\operatorname{PRCTF}\left(\chi^{2}=1.00 ; P=0.61\right)$. In contrast, only 9 of 120 families assessed for race QFCSC possessed entirely susceptible plants. This ratio was $15: 1$, indicative of two genes conferring resistance to race QFCSC $\left(\left(\chi^{2}=0.32 ; P=0.57\right)\right.$. The seedling ITs of race QFCSC ranged from $; 1-$ to $3+$. All plants in a total of 19 families exhibited seedling ITs to QFCSC of ;1-, ;11+, or ;13, indicative of homozygosity for Sr38. Similarly, 20 families with plants that possessed seedling ITs of 2-, 2, 2+, 3, or 3+ were classified as fixed for the absence of $\operatorname{Sr} 38$.

Tissue was harvested from 10 seedling plants in each $\mathrm{F}_{2: 3}$ family after assessing the seedling ITs. DNA was extracted from a bulk of 10 plants in each family using a BioSprint 96 DNA plant kit on the BioSprint workstation (QIAGEN). The DNA samples were assessed with a KASP marker linked to $\mathrm{Sr} 38$ according to previously described conditions (Hundie et al. 2019). The Sr38 KASP marker perfectly co-segregated with the Sr38 phenotypic classification among these 39 families and parents. Of the 19 families fixed for $\mathrm{Sr} 38$ based on phenotypes and genotypes, six families were resistant in response to PRCTF, eight were heterogeneous, and five were susceptible. Similarly, of the 20 families without $\mathrm{Sr} 38$, three were resistant in response to PRCTF, eight were heterogenous, seven were susceptible, and two were uncertain. These results indicated that VPM-1 carries another gene in addition to $\mathrm{Sr} 38$ that confers resistance to race PRCTF and other races derived from the samples collected in Georgia during the 2013 to 2015 seasons.

A representative set of 61 isolates derived from the 2013 to 2015 collections from Georgia was genotyped using a custom PgtSNP $3.0 \mathrm{k}$ chip. These 61 isolates came from 57 of the 68 viable $P$. graminis f. sp. tritici samples. A set of 26 reference isolates representing previously defined clades $\mathrm{I}$ to $\mathrm{V}$ was also genotyped (Olivera et al. 2015; Olivera Firpo et al. 2017). After filtering, 1,999 SNP loci were used for phylogenetic analysis. From the 61 Georgian isolates, 28 multilocus genotypes were identified that formed 17 distinct MLG groups, each corresponding to a specific clade or subclade. The 27 isolates derived from the 2013 collection, representing 12 of the 16 races, contained 11 of the 17 MLG groups

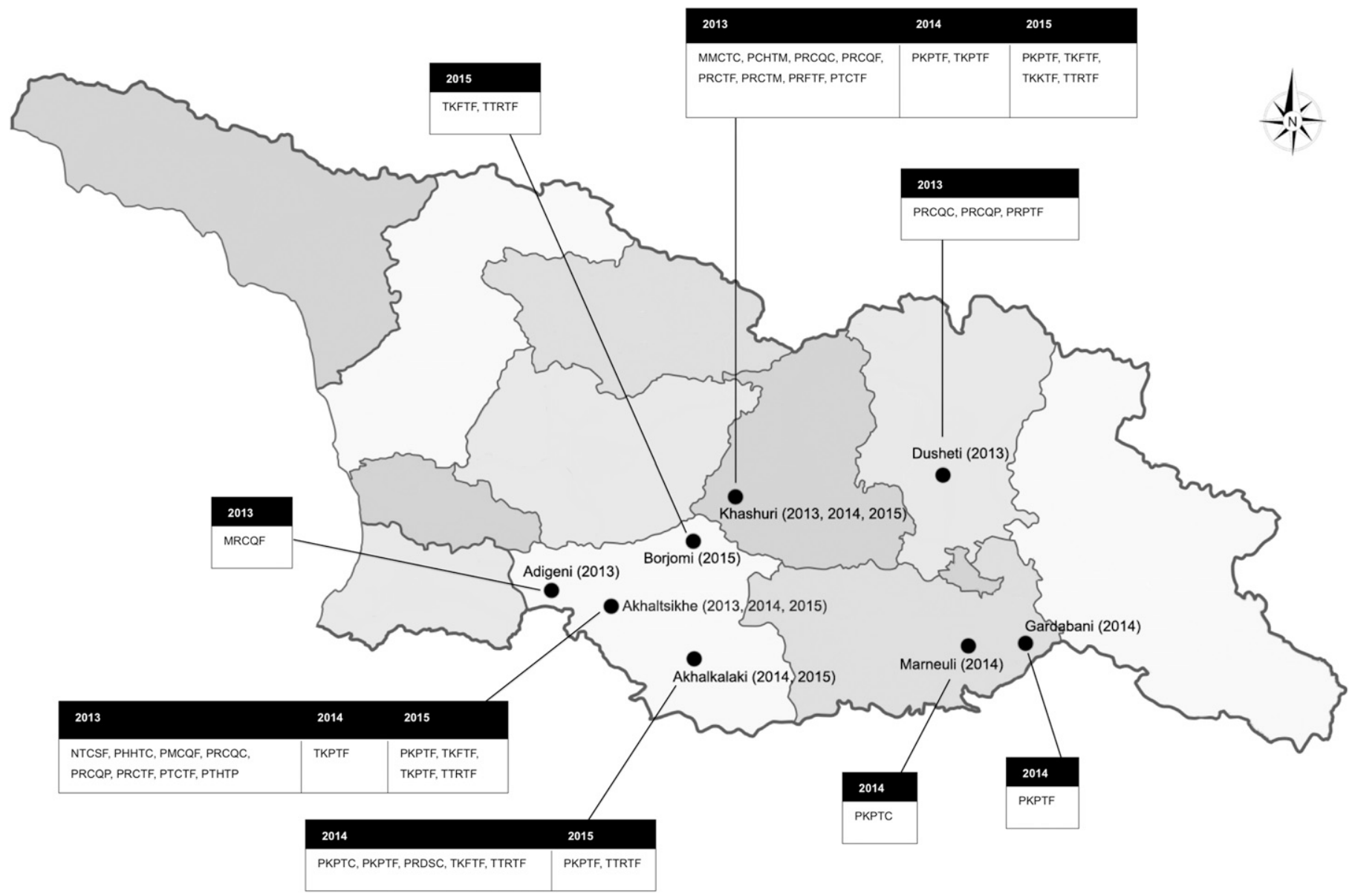

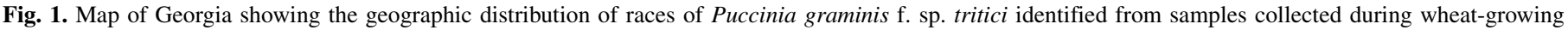
seasons in 2013, 2014, and 2015. Race nomenclature was based on the work of Roelfs and Martens (1988) and Jin et al. (2008). 
(Fig. 3). For 10 of these races, there was a one-to-one correlation between MLG group and race. An exception was that four isolates representing races PRCTC and PRCTM had the same genotype. These 11 MLG groups formed a cluster that included the reference isolates 13GER04-1 and 13GER05-1 (race MMMTF) designated clade V. Temporary subclade designations have been assigned to each of the MLG groups within clade V (Table 2). In contrast, the 34 isolates representing the 2014 and 2015 populations contained six of the 17 MLG groups. The majority of these isolates $(70.6 \%)$ belonged to clade IV: IV-A.1 (8.3\%); IV-C (50\%); IV-E.2 (37.5\%); and the new subclade IV-F (4.2\%). The remaining 10 isolates belonged to two different clades, clade III $(26.5 \%)$ and clade V (2.9\%) (Table 4). The six U.S. isolates were genetically distinct from clades I to V and formed a separate clade (VI).

Isolates of race PKPTF from the 2014 and 2015 Georgian collections were genotyped as clade IV-C. This subclade also included one isolate (14GEO210-2) with the race PKPTC designation. Isolates from 2015 samples of $P$. graminis f. sp. tritici race TKFTF belonged to clade IV-E.2, which also includes isolates
15GEO253-1 (TKPTF) and 15GEO267-1 (TKKTF). In contrast, the isolates derived from 2014 samples with race phenotypes of TKPTF (14GEO196 and 14GEO192-2) and TKFTF (14GEO190-2) were genotyped as clade IV-A.1 and clade IV-F, respectively. This supports the phenotypic data showing the previously described differences in wheat differential lines with $\mathrm{Sr} 35$ and Sr45. The nine isolates of race TTRTF comprised a new subgroup (clade III-B) of clade III. Isolate 14GEO182-3 (PRDSC) was the only isolate from the 2014 and 2015 collections that belonged to clade V.

The numbers of race phenotypes and SNP genotypes observed in the 2013 samples were higher compared with the 2014 and 2015 collections, suggesting that the 2013 population was derived through sexual recombination on barberry. Phenotypic diversity was shown to be higher in the 2013 set of isolates using Shannon's diversity index $(H=2.421)$ compared with $2014(H=1.316)$ and $2015(H=1.337)$. In a similar comparison, genotypic diversity was higher in the 2013 set of isolates, as shown by Stoddart and Taylor's index of MLG diversity $(G=23.1)$ compared with the 2014 to 2015 set of isolates $(G=11.23)$ To further test this hypothesis, the

TABLE 1. Seedling infection types (ITs) observed on stem rust differentials for 16 races of Puccinia graminis f. sp. tritici obtained from samples collected in Georgia in 2013

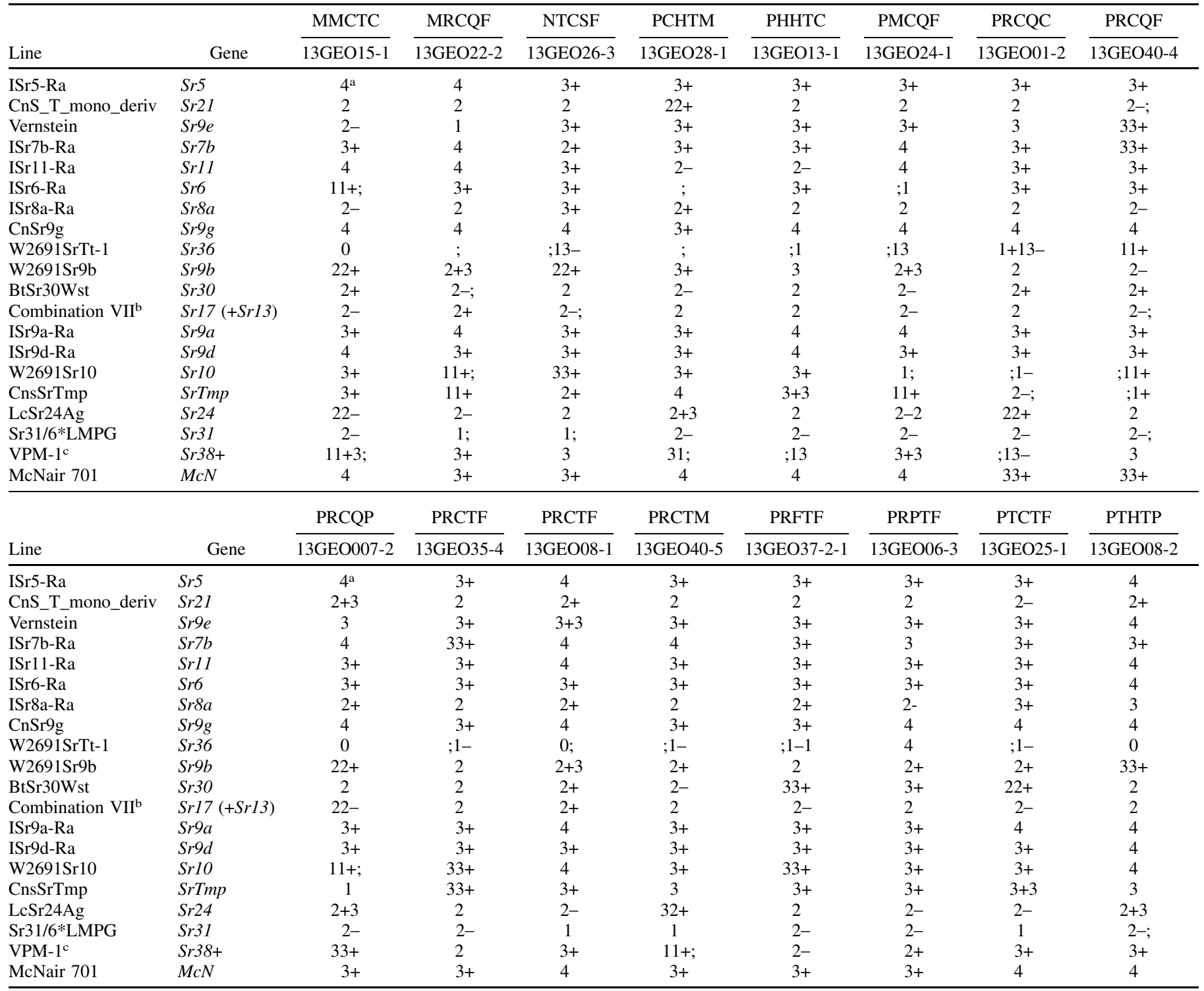

a ITs observed on seedlings at 14 days postinoculation using a scale of 0 to 4 scale according to the work of Stakman et al. (1962), where ITs of 0 , ; 1,2 , or combinations thereof are considered low IT, and ITs of 3 or higher are considered high IT.

b The low ITs produced by avirulent isolates on Sr17 are 0; to ;. ITs 2- or higher on this line indicate virulence to Sr17 but avirulence to $\operatorname{Sr} 13$.

c The low ITs produced by avirulent isolates on $\operatorname{Sr} 38$ are ; to 31;. ITs 2- to 2 on this line indicate virulence to $\operatorname{Sr} 38$ but avirulence to an additional gene identified on VPM-1. 
standardized index of association $\left(\operatorname{rbar}_{\mathrm{D}}\right.$ ) between the SNP markers was calculated using a clone-corrected dataset containing a single isolate for each of the MLG groups. The resulting 12 isolates from clade $\mathrm{V}$ showed no significant linkage disequilibrium across the SNP loci $\left(\operatorname{rbar}_{\mathrm{D}}=1.4 \mathrm{e}-4 ; P=0.213\right)$, thus supporting the hypothesis that these isolates were derived from a sexual population. Using the same approach, the standardized index of association was calculated for the five isolates representing clades III-B and IV and showed significant linkage disequilibrium $\left(\operatorname{rbar}_{\mathrm{D}}=0.0715 ; P=0.001\right)$ among the SNP loci, indicating that the predominant Georgian $P$. graminis f. sp. tritici populations in 2014 and 2015 were asexual. The one exception to this is isolate
14GEO182-3 (PRDSC, clade V-M), which was included in the 2013 dataset for this analysis.

\section{DISCUSSION}

Stem rust is a persistent disease of wheat in Georgia, and annual national rust surveys have shown that the incidence and severity of this disease vary from year to year (Sikharulidze et al. 2015). A key component to successful management of stem rust is the deployment of wheat varieties with effective stem rust resistance genes. A better understanding of the pathogen population is essential for facilitating the development of gene deployment strategies.

TABLE 2. Representative isolates, genotype, frequency of occurrence, and infection types (ITs) produced on selected wheat lines carrying important stem rust resistance genes of 16 races of Puccinia graminis f. sp. tritici derived from wheat stem rust samples collected in Georgia in 2013

\begin{tabular}{|c|c|c|c|c|c|c|c|c|c|}
\hline Race & Representative isolate & Genotype & Frequency $(\%)$ & $\operatorname{Sr} 22^{\mathrm{a}}$ & Sr35 & Sr37 & $S r 44$ & $\operatorname{Sr} 50$ & Sr9e, 13+ \\
\hline MMCTC $^{\mathrm{b}}$ & 13GEO15-1 & Clade V-B & 4.2 & $2-; c$ & 0 & $1 ;$ & $3+$ & $2-$ & ; \\
\hline MRCQF & 13GEO22-2 & Clade V-C & 4.2 & ;2- & ;1- & ;1- & $11-$ & $1-;$ & ; \\
\hline NTCSF & 13GEO26-3 & $\mathrm{nd}^{\mathrm{d}}$ & 4.2 & $2-$ & 0 & 1 & ;3- & $; 2-$ & 0 \\
\hline PHHTC & 13GEO13-1 & Clade V-E & 4.2 & $2-$ & 0 & $; 1$ & $; 1-$ & $2-$ & ; \\
\hline PMCQF & 13GEO24-1 & Clade V-F & 4.2 & 2 & 0 & ;1- & ;2- & ; & 0 \\
\hline PRCQC & 13GEO01-2 & Clade V-G & 20.8 & $2-;$ & 0 & ; & $2-$ & $2-$ & ; \\
\hline PRCQF & 13GEO40-4 & nd & 4.2 & $; 2-$ & ; & ; & $2+3-$ & ;1- & 0 \\
\hline PRCTF & 13GEO08-1 & Clade V-J & 12.4 & $2-$ & ; & $; 1$ & $2-;$ & 1 & 0 \\
\hline PRCTM & 13GEO40-5 & Clade V-I & 4.2 & 3 & 0 & ;1- & 1 & $22-$ & 0 \\
\hline PRFTF & 13GEO37-2-1 & nd & 4.2 & $2-$ & 0 & ;1- & $3+$ & $2-$ & ; \\
\hline PRPTF & 13GEO06-3 & Clade V-K & 4.2 & $2-$ & $3+$ & $; 1$ & $2+3$ & $; 1-$ & ; \\
\hline PTCTF & 13GEO25-1 & Clade V-L & 20.8 & $2-$ & 0 & $; 1$ & $33+$ & 1 & 0 \\
\hline PTHTP & 13GEO08-2 & nd & 4.2 & ;2- & ; & ;1- & $3+$ & 0 & 0 \\
\hline
\end{tabular}

a Wheat lines carrying Sr22 (SwSr22T.B.), Sr35 (Mq(2)5XG2919), Sr37 (W3563), Sr44 (TAF 2), Sr50 (Fed*3/Gabo*51BL.1RS-1-1), and Sr9e, 13+ (Leeds).

b Race nomenclature was based on the work of Roelfs and Martens (1988) and Jin et al. (2008).

c ITs observed on seedlings at 14 days postinoculation using a scale of 0 to 4 according to the work of Stakman et al. (1962), where ITs of 0,;, 1, or 2, are considered low IT and ITs of 3 or higher are considered as high IT.

d nd, no data.

TABLE 3. Seedling infection types (ITs) observed on stem rust differentials for nine races of Puccinia graminis f. sp. tritici obtained from samples collected in Georgia in 2014 and 2015

\begin{tabular}{|c|c|c|c|c|c|c|c|c|c|c|}
\hline & & РКPTC & PKPTF & PRDSC & TKFTF & TKFTF & TKKTF & TKPTF & TKPTF & TTRTF \\
\hline Line & Gene & 14GEO210-2 & 14GEO179-1 & 14GEO182-3 & 14GEO190-2 & 15GEO239-1 & 15GEO267-1 & 14GEO196 & $\overline{15 \mathrm{GEO} 253-1}$ & 14GEO189-4-1 \\
\hline $\begin{array}{l}\text { ISr5-Ra } \\
\text { CnS_T_- } \\
\text { mono_deriv }\end{array}$ & $\operatorname{Sr} 5$ & $3 t^{\mathrm{a}}$ & $3+$ & $3+$ & $3+$ & $3+$ & $3+$ & 4 & $3+$ & $3+$ \\
\hline Vernstein & Sr9e & $3+$ & $3+$ & $3+$ & $3+$ & $3+$ & $3+$ & 4 & $3+$ & $3+$ \\
\hline ISr7b-Ra & $S r 7 b$ & $3+$ & $3+$ & $3+$ & $3+$ & $3+$ & 3 & $33+$ & $3+$ & $3+$ \\
\hline ISr11-Ra & Srl1 & $; 2-$ & $2-$ & $3+$ & $2-$ & $2-$ & $2-$ & $2-$ & $2-$ & $3+$ \\
\hline $\mathrm{CnSr} 9 \mathrm{~g}$ & $\operatorname{Sr} 9 g$ & $3+$ & 4 & 4 & $3+$ & $3+$ & $3+$ & $3+$ & $3+$ & $3+$ \\
\hline W2691SrTt-1 & Sr36 & $33+$ & $33+$ & $; 1-$ & $; 1-$ & 0 & $; 11+$ & $3+$ & $3+$ & $3+$ \\
\hline W2691Sr9b & $\operatorname{Sr} 9 b$ & 2 & $2+$ & $22-$ & $2+3$ & $2+3$ & $33+$ & $32+$ & $2+$ & $3+$ \\
\hline BtSr30Wst & Sr30 & $3+3$ & $3+$ & 3 & $3+$ & $3+$ & $3+$ & $3+$ & $3+$ & $2-$ \\
\hline $\begin{array}{l}\text { Combination } \\
\text { VII }^{\mathrm{b}}\end{array}$ & $\begin{array}{l}\text { Sr17 } \\
\quad(+\operatorname{Sr} 13)\end{array}$ & $2-$ & $2-$ & ; & 2 & 2 & 2 & $2+$ & $2-$ & $22-$ \\
\hline ISr9a-Ra & $\operatorname{Sr} 9 a$ & $3+$ & $3+$ & $3+$ & $3+$ & $3+$ & $3+$ & $3+$ & $3+$ & $3+$ \\
\hline \multirow{3}{*}{$\begin{array}{l}\text { Sr31/ } \\
\text { 6*LMPG } \\
\text { VPM-1 } \\
\text { McNair } 701 \\
\end{array}$} & Sr31 & $1-;$ & $2-;$ & $2-$ & $2-$ & $2-;$ & $2-$ & $2-$ & $2-;$ & $2-;$ \\
\hline & Sr38+ & 1 & $22+$ & $11+;$ & $2+3$ & 3 & $3+$ & 3 & $32+$ & $2+$ \\
\hline & $M c N$ & $3+$ & 4 & $3+$ & 4 & 4 & 4 & 4 & 4 & 4 \\
\hline
\end{tabular}

${ }^{a}$ ITs observed on seedlings at 14 days postinoculation using a scale of 0 to 4 according to Stakman et al. (1962), where ITs of 0 ,;, 1, 2, or combinations thereof are considered low IT and ITs of 3 or higher are considered a high IT.

b The low ITs produced by avirulent isolates on Sr17 are 0; to ;. ITs 2- or higher on this line indicate virulence to $\operatorname{Sr} 17$ but avirulence to $\operatorname{Sr} 13$.

c The low ITs produced by avirulent isolates on $\operatorname{Sr} 38$ are ; to 31 ;. ITs $2-$ to $2+$ on this line indicate virulence to $\operatorname{Sr} 38$ but avirulence to an additional gene identified on VPM-1. 
Of the 23 races identified in this study, 16 of these were from the 2013 collection. SNP genotyping showed similar results, with 11 novel MLG groups from 27 isolates representing 12 of the 16 races in the 2013 collection. Higher levels of phenotypic and genotypic diversities suggested that the isolates derived from stem rust samples collected in 2013 were of sexual origin. Two species of barberry were reported in Georgia: common barberry (B. vulgaris) and Georgian barberry (B. iberica Stev. Et Fisch.) (Lachashvili et al. 2017; Maghradze et al. 2012). Common barberry is known to be highly susceptible to the wheat stem rust pathogen, whereas Georgian barberry has been reported to be moderately susceptible (Levine and Cotter 1932). The presence of the alternate host of the stem rust pathogen near wheat fields has the potential to increase the pathogen genetic diversity through genetic recombination, including generating novel virulence combinations. The alternate host could also have a role in disease epidemiology by providing the source of initial inoculum. Common barberry is distributed in the Georgian regions of Meskheti, Shida Kartli, Samachablo, and Kakheti (Ketskhoveli and Gagnidze 2007). Not surprisingly, the highest levels of stem rust infections in 2009 to 2013 in Georgia occurred in the Meskheti region, where common barberry is widely distributed (Sikharulidze et al. 2015). The wide distribution of barberry in wheat-growing areas and the presence of a more diverse $P$. graminis f. sp. tritici population observed in the 2013 samples indicate that Georgia is a hotspot of $P$. graminis diversity with high potential for generating new virulent combinations.

A change in the pathogen population occurred in 2014 and 2015, such that none of the races identified in 2013 were recovered in the 2014 and 2015 collections; instead, fewer races with higher virulence were observed. This may explain why the severity and incidence observed in wheat fields in 2014 and 2015 were higher compared with the levels observed in the 2013 wheat surveys. In addition, the majority of the races identified in 2014 and 2015 were not genotypically related to the ones recovered in 2013. The 2013 isolates belong to clade V, whereas the 2014 and 2015 isolates primarily belong to clade III and clade IV. This may indicate that the alternate host did not have a role in the 2014 and 2015 seasons, and that the more virulent races might be a result of selection by resistance genes in the dominant cultivars from an asexual population that pre-existed in a larger geographical scale. This would explain the phenomenon of fewer races with increased virulence. Although it is difficult to postulate which resistance genes might have had a role in the selection for the rust population without investigating what stem rust resistance genes may be present in cultivars, a near-complete change from avirulence to virulence on $\mathrm{Sr} 28$ may implicate this gene.

With the recent development of genotyping tools for $P$. graminis f. sp. tritici, the phylogenetic relationships between isolates of critical races are beginning to be elucidated. Genotyping studies of representative $P$. graminis $\mathrm{f}$. $\mathrm{sp}$. tritici isolates from East Africa, Middle East, and Europe identified five well-supported clades (Olivera et al. 2015; Olivera Firpo et al. 2017). Isolates representing the $\mathrm{Ug} 99$ race group were designated clade $\mathrm{I}$, which is most closely related to the African isolates of race JRCQC (clade II). Clade III is composed of isolates of the TRTTF race group, which is common to northeast Africa and the Middle East. Isolates of TKTTF and related races comprise clade IV. This is a complex clade with seven subclades. Ethiopian isolates of race TKTTF belonged to subclades IV-A.1 and IV-B, whereas the isolates of race TKTTF from Germany belonged to subclades IV-A.1 and IV-A.2. German isolates of race MMMTF comprised clade V. The majority of P. graminis f. sp. tritici isolates representing the 2014 and 2015 collections belonged to SNP clade IV and were divided among three subgroups IV-A, IV-C, and IV-E.2. Genotype data from selected isolates representing the TKTTF race group derived from 2013 collections from Ethiopia and Germany established phylogenetic clade IV and delineated seven distinct subclades (Olivera et al. 2015; Olivera Firpo et al. 2017). Additional genotyping studies have shown that both IV-A.1 and IV-A.2 have broad geographical distributions from northern Europe through the Middle East and into northeastern Africa (L. J. Szabo, unpublished data). The finding of two isolates (14GEO192-2 and 14GEO196, TKPTF) that belonged to clade IV-A.1 from the 2014 Georgian samples is consistent with these being a part of a larger asexual population. Although race TKTTF has been widely distributed in Turkey and the Middle East, this race was not identified from samples collected from Georgia during 2013 to 2015. Clades IV-C and IV-E. 2 were

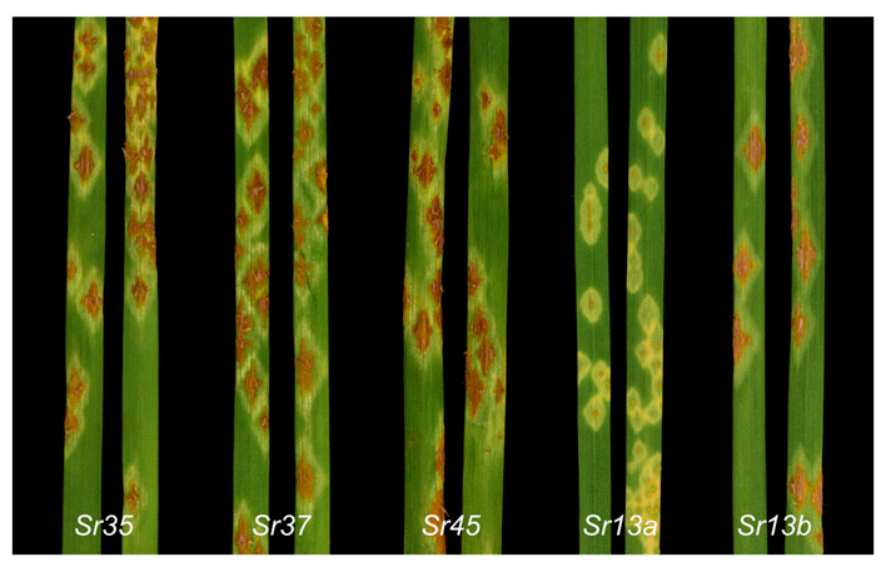

Fig. 2. Infection types produced by race TTRTF of Puccinia graminis f. sp. tritici on lines carrying $\mathrm{Sr} 13 a, \mathrm{Sr} 13 b, \mathrm{Sr} 35, \mathrm{Sr} 37$, and $\mathrm{Sr} 45$.

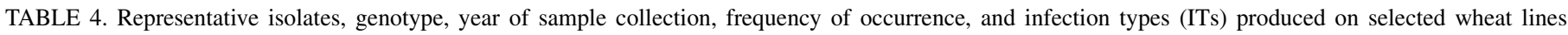

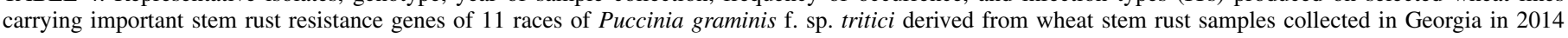
and 2015

\begin{tabular}{|c|c|c|c|c|c|c|c|c|c|c|}
\hline Race & Representative isolate & Genotype & Year & Frequency $(\%)$ & $\operatorname{Sr} 22^{\mathrm{a}}$ & Sr35 & Sr37 & $\mathrm{Sr} 44$ & $\operatorname{Sr} 50$ & Sr9e, 13+ \\
\hline PKPTC $^{b}$ & 14GEO210-2 & Clade IV-C & 2014 & 13.3 & $2-; c$ & 0 & ;1- & 32 & $2-$ & 0 \\
\hline PKPTF & 14GEO179-1 & Clade IV-C & 2014 & 66.7 & $2-$ & 0 & ;1- & 3 & $2-$ & 0 \\
\hline PRDSC & 14GEO182-3 & Clade V-M & 2014 & 6.7 & $2-$ & 0 & ;2- & $2+$ & $2-$ & 0 \\
\hline TKFTF & 14GEO190-2 & Clade IV-F & 2014 & 6.7 & $22-$ & 0 & ;13 & 3 & $2-$ & 0 \\
\hline TKPTF & 14GEO196 & Clade IV-A.1 & 2014 & 13.3 & $2-$ & ;1- & ;13 & $33+$ & 0 & ; \\
\hline TTRTF & 14GEO189-4-1 & Clade III-B & 2014 & 6.7 & $2-$ & $33+$ & $3+$ & $2+$ & $2+3-$ & $3+$ \\
\hline PKPTF & 15GEO243-1 & Clade IV-C & 2015 & 17.2 & $2-$ & ; & $; 1$ & $3+3$ & $2-$ & ; \\
\hline TKFTF & 15GEO239-1 & Clade IV-E.2 & 2015 & 37.9 & $2-$ & $3+$ & $; 1$ & $3+$ & 0 & 0 \\
\hline TKKTF & 15GEO267-1 & Clade IV-E.2 & 2015 & 3.4 & $2-$ & $3+$ & $; 11+$ & $3+$ & ; & ; \\
\hline TKPTF & 15GEO253-1 & Clade IV-E.2 & 2015 & 6.9 & 2 & $33+$ & $; 11+$ & $3+$ & $2-$ & ; \\
\hline TTRTF & 15GEO257-1 & Clade III-B & 2015 & 34.5 & $2-$ & $33+$ & $3+$ & $2+3$ & $2+3$ & $3+$ \\
\hline
\end{tabular}

a Wheat lines carrying Sr22 (SwSr22T.B.), Sr35 (Mq(2)5XG2919), Sr37 (W3563), Sr44 (TAF 2), Sr50 (Fed*3/Gabo*51BL.1RS-1-1), and Sr9e, 13+ (Leeds).

b Race nomenclature was based on the work of Roelfs and Martens (1988) and Jin et al. (2008).

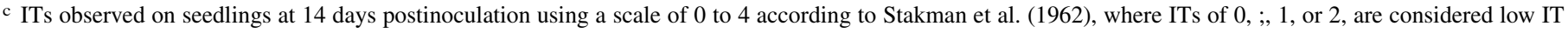
and ITs of 3 or higher are considered high IT. 
first defined from the 2013 German collections and consisted of isolates with $P$. graminis f. sp. tritici race PKPTF, TKPTF, and TKKTF, respectively. Both of these genotypes represent predominant members of the 2014 and 2015 collections from Georgia, indicating that these two subclades are also widely distributed. Two races (PKPTC and PKPTF) were identified in the isolates from the Georgian collections belonging to clade IV-C, and three races (TKFTF, TKKTF, and TKPTF) were identified from isolates belonging to clade IV-E.2. An additional subclade was identified from the 2014 collections. Isolate 14GEO190-2 was genotyped as clade IV-F and phenotyped as TKFTF. The placement of isolate 14GEO190-2 into clade IV-F, separate from the 2015 isolates with the same race (IV-E.2), is supported by differences in ITs on $\mathrm{Sr} 35$ and Sr45. Although the 14GEO190-2 isolate had low ITs for both of these genes, all 2015 isolates of race TKFTF had high ITs for these genes. This was also true for isolates 14GEO192-2 and 14GEO96

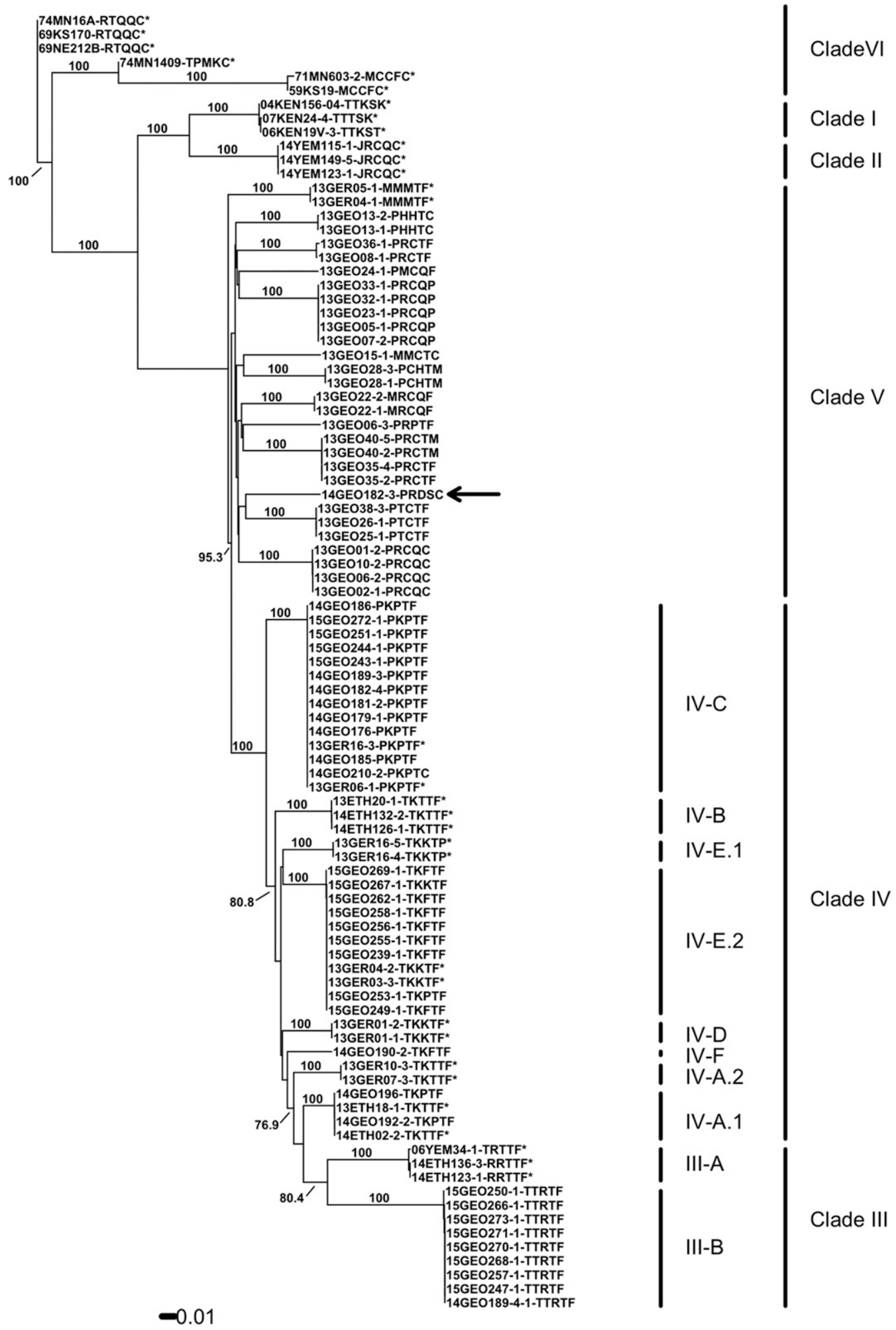

Fig. 3. Neighbor-joining phylogenetic tree of 61 Georgian Puccinia graminis f. sp. tritici isolates from 2013, 2014, and 2015 collections based on 1,999 singlenucleotide polymorphism loci. Thirty-two reference isolates were included in the analysis $(*)$. Clades, subclades, and race are indicated. Bootstrap values for 5,000 replicates are shown $(>75 \%)$. Branch lengths are measured in the number of substitutions per site. 
(TKPTF, clade IV-A.1), which showed low ITs on Sr35 and Sr45 and differed from isolate 15GEO253-1 (TKPTF, clade IV-E.2), which had high ITs on these genes.

The most important virulence combination identified in Georgia in the 2013 to 2015 surveys is race TTRTF. This race, first observed in 2014 in Georgia, has a wide virulence spectrum, including virulence to $S r 13 b, S r 35$, and $S r 37$ and moderate virulence to $S r 50$, which are important genes for $\mathrm{Ug} 99$ resistance breeding. Isolates with virulence to $S r l 3 b$ are rare, and it was previously found only in race JRCQC in Ethiopia (Olivera et al. 2012). $S r 13 b$ is one of three known alleles at the Srl3 locus (Zhang et al. 2017), and together they serve as the main component for stem rust resistance in durum wheat worldwide (Klindworth et al. 2007; Luig 1983; Qamar et al. 2009; Singh et al. 2015).

Race-typing of $P$. graminis f. sp. tritici isolates based on the virulence/avirulence pattern on a set of differential lines requires a clear understanding of the genetics of stem rust resistance in each line and the phenotypic expression of the genes. Monogenic lines are preferable in a differential set; however, additional genes that can only be identified through the evaluation of unique races may be present in the genetic background. The unusual ITs observed on Sr38 (ITs 2- to 32+) in a number of isolates derived in this study suggested the possibility of an additional stem rust resistance gene present in line VPM1. Inheritance studies and marker evaluations confirmed the presence of an additional gene in VPM1 that confers a low IT that is different to the one by Sr38. This gene, when effective in a particular isolate, can only be detected if $\mathrm{Sr} 38$ is ineffective. Based on these results, in the nomenclature system, Sr38 can only be considered as having a low IT or effective in a particular isolate if the phenotype observed is ; to 31 ;. We are currently developing an $\mathrm{Sr} 38$ monogenic line derived from VPM1 that will replace our current source of $\operatorname{Sr} 38$ in the differential set.

Three races observed in Georgia during 2013 to 2015 exhibited two variants based on the virulence on $S r 22$ (PRCTF) and virulence on Sr35 and Sr45 (TKFTF and TKPTF). These variants would not have been identified if only the differential set of 20 was used to characterize these $P$. graminis f. sp. tritici isolates. A similar situation was observed with isolates derived from samples collected in Germany in 2013 that were race-typed as TKTTF (Olivera Firpo et al. 2017). Two clearly distinct variants of race TKTTF were detected in Germany that differ in the virulence to three genes $(\mathrm{Sr} 7 a$, $S r 45$, and SrTt-3) that were not present in the standard 20 differential lines currently used. Because an increasing number of cases of newly identified races cannot be delineated by the 20 differential lines, there is a need to expand differential sets to include new genes that allow greater differentiation of the contemporary P. graminis populations worldwide.

Genotyping placed isolates of race TTRTF into a new subclade (III-B) of clade III, which is related to the subclade III-A that includes races in the TRTTF group (Olivera et al. 2015). Race TRTTF, identified in Yemen (2006) and Ethiopia (2009), was also reported to be virulent to $\mathrm{Sr} 13$ (Olivera et al. 2012). Race TTRTF was detected in 2016 and 2017 in Sicily, Italy, where it caused a severe epidemic on durum wheat (Bhattacharya 2017; Patpour et al. 2017). This race was also identified in Hungary in 2017 (P. Olivera and Y. Jin, unpublished data), and in Ethiopia in 2017 (W. Bulbula and E. Abera, unpublished data). Preliminary data suggested that race TTRTF exhibits a similar dispersion pattern and geographic distribution similar to race TKTTF. These results indicated that the Caucasus region may have had an important role in generating and dispersing $P$. graminis f. sp. tritici spores to other wheat-growing regions. Airborne dispersal simulations by Meyer et al. (2017b) indicated that spore dispersal occurs from Georgia toward Eastern Europe. This may explain the identification of race TTRTF in Hungarian wheat fields in 2017, and its potential migration from Eastern to Central and Western Europe. Although dispersal simulations performed by Meyer et al. (2017a) ruled out direct airborne transport from Georgia and Turkey into Ethiopia, they indicated an airborne spread of race TKTTF from the Middle East into East Africa via Yemen. The same dispersal pattern may have occurred with race TTRTF as it moved from the Caucasus to Ethiopia.

Since the re-emergence of wheat stem rust in East Africa, increased surveillance and pathogen monitoring activities have allowed the detection of recent stem rust outbreaks and the identification of novel virulence combinations that render effective resistance genes in breeding germplasm and released cultivars ineffective. The frequent stem rust incidence and presence of the alternate host near wheat production make Georgia an ideal location for investigating the roles of the alternate host in stem rust pathogen variations and disease epidemiology. New races with unique virulence combinations, first identified in Georgia, have been observed in a much wider geographical area. Therefore, efforts must continue to monitor the local pathogen population to detect novel virulence that can have an impact on a global scale.

\section{ACKNOWLEDGMENTS}

We thank Jerry Johnson and Sam Gale (USDA-ARS Cereal Disease Laboratory) and Melissa Carter (USDA-ARS Foreign Disease-Weed Science Research Unit) for their technical assistance.

\section{LITERATURE CITED}

Agapow, P.-M., and Burt, A. 2001. Indices of multilocus linkage disequilibrium. Mol. Ecol. Resour. 1:101-102.

Bhattacharya, S. 2017. Deadly new wheat disease threatens Europe's crops. Nature 542:145-146.

Groth, J. V., and Roelfs, A. P. 1987. The concept and measurement of phenotypic diversity in Puccinia graminis on wheat. Phytopathology 77:1395-1399.

Hundie, B., Girma, B., Tadesse, Z., Edae, E., Olivera Firpo, P. D., Abera, E. H., Bulbula, W. D., Abeyo, B., Badebo, A., Cisar, G., Brown-Guedira, G., Gale, S., Jin, Y., and Rouse, M. N. 2019. Characterization of Ethiopian wheat germplasm for resistance to four Puccinia graminis f. sp. tritici races facilitated by single race nurseries. Plant Dis. 103:2359-2366.

Jin, Y., Singh, R. P., Ward, R. W., Wanyera, R., Kinyua, M., Njau, P., Fetch, T., Pretorius, Z. A., and Yahyaoui, A. 2007. Characterization of seedling infection types and adult plant infection responses of monogenic $\mathrm{Sr}$ gene lines to race TTKS of Puccinia graminis f. sp. tritici. Plant Dis. 91: 1096-1099.

Jin, Y., Szabo, L. J., Pretorius, Z. A., Singh, R. P., Ward, R., and Fetch, T. 2008. Detection of virulence to resistance gene $S r 24$ within race TTKS of Puccinia graminis f. sp. tritici. Plant Dis. 92:923-926.

Kamvar, Z. N., Brooks, J. C., and Grünwald, N. J. 2015. Novel R tools for analysis of genome-wide population genetic data with emphasis on clonality. Front. Genet. 6:208.

Ketskhoveli, N., and Gagnidze, R. 2007. Flora of Georgia. 1971-2007. Volume 15. 2nd edition. Tbilisi, Georgia.

Klindworth, D. L., Miller, J. D., Jin, Y., and Xu, S. S. 2007. Chromosomal locations of genes for stem rust resistance in monogenic lines derived from tetraploid wheat accession ST464. Crop Sci. 47:1441-1450.

Lachashvili, N. J., Eradza, N. V., and Khetsuriani, L. D. 2017. Conspectus of trees and shrubs of Tbilisi environs (East Georgia, South Caucasus). Ann. Agric. Sci. 15:118-129.

Levine, M. N., and Cotter, R. U. 1932. Susceptibility and resistance of Berberis and related genera to Puccinia graminis. USDA Tech. Bull. 300: $1-27$.

Lewis, C. M., Persoons, A., Bebber, D. P., Kigathi, R. N., Maintz, J., Findlay, K., Corredor-Moreno, P., Harrington, S. A., Kangara, N., Berlin, A., Garcia, R., German, S. E., Hanzalova, A., Hodson, D., Hovmoller, M. S., Huerta-Espino, J., Imitaz, M., Iqbal Mirza, J., Justesen, A. F., Niks, R. E., Omarani, A., Patpour, M., Pretorius, Z. A., Roohparvar, R., Sela, H., Singh, R. P., Steffenson, B., Visser, B., Fenwick, P. M., Thomas, J., Wulff, B. B., and Saunders, D. G. O. 2018. Potential for re-emergence of wheat stem rust in the United Kingdom. Commun. Biol. 1:13.

Luig, N. H. 1983. A survey of virulence genes in wheat stem rust Puccinia graminis f. sp. tritici. Supplement 11 to Journal Plant Breeding In: Advances in Plant Breeding. Paul Parey, Berlin.

Maghradze, D., Bobokashvili, Z., and Kvaliashvili, V. 2012. Minor and underutilized fruits in Georgia and their wild relatives. Pages 41-48 in: ISHS Acta Horticulturae 948: International symposium on wild relatives of subtropical and temperate fruit and nut Crops. M. K. Aradhya and D. A. Kluepfel, eds. International Society for Horticultural Science, Leuven, Belgium. 
Mert, Z., Karakaya, A., Dusunceli, F., Akan, K., and Cetin, L. 2012. Determination of Puccinia graminis f. sp. tritici races of wheat in Turkey. Turk. J. Agric. For. 36:107-120.

Meyer, M., Burgin, L., Hort, M. C., Hodson, D. P., and Gilligan, C. A. 2017a. Large-scale atmospheric dispersal simulations identify likely airborne incursion routes of wheat stem rust into Ethiopia. Phytopathology 107:1175-1186.

Meyer, M., Cox, J. A., Hitchings, M. T. D., Burgin, L., Hort, M. C., Hodson, D. P., and Gilligan, C. A. 2017b. Quantifying airborne dispersal routes of pathogens over continents to safeguard global wheat supply. Nat. Plants 3: 780-786.

Nei, M. 1972. Genetic distance between populations. Am. Nat. 106:283-292.

Nei, M. 1978. Estimation of average heterozygocity and genetic distance from a small number of individuals. Genetics 89:583-590.

Newcomb, M., Olivera, P. D., Rouse, M. N., Szabo, L. J., Johnson, J., Gale, S., Luster, D. G., Wanyera, R., Macharia, G., Bhavani, S., Hodson, D., Patpour, M., Hovmoller, M. S., Fetch, T. G., Jr., and Jin, Y. 2016. Kenyan isolates of Puccinia graminis f. sp. tritici from 2008 to 2014: Virulence to SrTmp in the Ug99 race group and implications for breeding programs. Phytopathology 106:729-736.

Olivera, P., Newcomb, M., Szabo, L. J., Rouse, M. N., Johnson, J., Gale, S., Luster, D. G., Hodson, D., Cox, J. A., Burgin, L., Hort, M., Gilligan, C. A., Patpour, M., Justesen, A. F., Hovmoller, M. S., Woldeab, G., Hailu, E., Hundie, B., Tadesse, K., Pumphrey, M., Singh, R. P., and Jin, Y. 2015. Phenotypic and genotypic characterization of race TKTTF of Puccinia graminis f. sp. tritici that caused a wheat stem rust epidemic in southern Ethiopia in 2013/14. Phytopathology 105:917-928

Olivera, P. D., Jin, Y., Rouse, M., Badebo, A., Fetch, T., Jr., Singh, R. P., and Yahyaoui, A. 2012. Races of Puccinia graminis f. sp. tritici with combined virulence to $\mathrm{Sr} 13$ and $S r 9 e$ in a field stem rust screening nursery in Ethiopia. Plant Dis. 96:623-628.

Olivera Firpo, P. D., Newcomb, M., Flath, K., Szabo, L. J., Carter, M., Luster, D. G., and Jin, Y. 2017. Characterization of Puccinia graminis f. sp. tritici isolates derived from an unusual wheat stem rust outbreak in Germany in 2013. Plant Pathol. 66:1258-1266.

Park, R., Fetch, T., Hodson, D., Jin, Y., Nazari, K., Prashar, M., and Pretorius, Z. 2011. International surveillance of wheat rust pathogens: Progress and challenges. Euphytica 179:109-117.

Patpour, M., Hovmoller, M. S., Hansen, J. G., Justesen, A. F., Thach, T., Rodriguez-Algaba, J., Hodson, D., and Randazo, B. 2017. Epidemics of yellow rust and stem rust in Southern Italy 2016-2017. https://www. globalrust.org/content/epidemics-yellow-and-stem-rust-southern-italy-2016-2017
Pretorius, Z. A., Singh, R. P., Wagoire, W. W., and Payne, T. S. 2000. Detection of virulence to wheat stem rust resistance gene Sr31 in Puccinia graminis f. sp. tritici in Uganda. Plant Dis. 84:203.

Qamar, Z., Bansal, U. K., and Bariana, H. S. 2009. Genetics of stem rust resistance in three durum wheat cultivars. Int. J. Plant Breed. 3:99-102.

Roelfs, A. P., and Martens, W. J. 1988. An international system of nomenclature for Puccinia graminis f. sp. tritici. Phytopathology 78:526-533.

Roelfs, A. P., Singh, R. P., and Saari, E. E. 1992. Rust diseases of wheat, concepts and methods of disease management. CIMMYT, Mexico City, Mexico.

Saitou, N., and Nei, M. 1987. The neighbor-joining method: A new method for reconstructing phylogenetic trees. Mol. Biol. Evol. 4:406-425.

Shamanin, V., Salina, E., Zelenskiv, Y., Kokhmetova, A., Patpour, M., Holmoller, M., Olivera, P., Szabo, L., Jin, Y., Meyer, M., Gilligan, C., Hort, M., Hodson, D., and Morgunov, A. 2018. Large scale wheat stem rust outbreaks in Western Siberia/Northern Kazakhstan in 2015-2017. https:// www.globalrust.org/content/large-scale-wheat-stem-rust-outbreaks-westernsiberia-northern-kazakhstan-2015-2017

Sikharulidze, Z., Bedoshvili, D., Mgeladze, L., Natsarishvili, K., and Chkhutiashvili, N. 2009. Screening wheat germplasm for resistance to stem rust in Georgia. http://www.globalrust.org/sites/default/files/2009\%20BGRI $\%$ 20poster\%20abstracts-Breeding\%20Rust\%20Resistant\%20Wheat.pdf

Sikharulidze, Z., Natsarishvili, K., Dumbadze, R., Mgeladze, L., and Tsetskhladze, T. 2015. Monitoring of cereal rusts in Georgia in 2009-2013. Biol. Forum 7:721-725.

Singh, R. P., Hodson, D. P., Jin, Y., Lagudah, E. S., Ayliffe, M. A., Bhavani, S., Rouse, M. N., Pretorius, Z. A., Szabo, L. J., Huerta-Espino, J., Basnet, B. R., Lan, C., and Hovmøller, M. S. 2015. Emergence and spread of new races of wheat stem rust fungus: Continued threat to food security and prospects of genetic control. Phytopathology 105:872-884.

Stakman, E. C., Steward, D. M., and Loegering, W. Q. 1962. Identification of physiological races of Puccinia graminis var. tritici. U.S. Dep. Agric. ARS. E-617.

Stoddart, J. A., and Taylor, J. F. 1988. Genotypic diversity: Estimation and prediction in samples. Genetics 118:705-711.

Zhang, W., Chen, S., Abate, Z., Nirmala, J., Rouse, M. N., and Dubcovsky, J. D. 2017. Identification and characterization of $\mathrm{Sr} 13$, a tetraploid wheat gene that confers resistance to the Ug99 stem rust race group. PNAS 114: E9483-E9492.

Zhao, S., Jing, W., Samuels, D. C., Sheng, Q., Shyr, Y., and Guo, Y. 2018. Strategies for processing and quality control of Illumina genotyping arrays. Brief. Bioinform. 19:765-775. 